\title{
Growth Charateristics and Yield Effect of Plant Spacing and Intercropping Maize and Cowpea
}

\author{
Abdulraheem Mukhtar Iderawumi ${ }^{1}$, Omogoye Adewale $\mathrm{Mubo}^{2}$, Charles Eneminyene Friday ${ }^{3}$ \\ ${ }^{1,2}$ Department of Agricultural Education, The College of Education, Lanlate, Oyo State, NIGERIA \\ ${ }^{3}$ Nigeria Institutes for Oil palm Research, Benin City, Edo State, NIGERIA \\ ${ }^{*}$ Corresponding Contact: \\ Email: m.iderawumi@gmail.com
}

\begin{abstract}
The trial was carried out at the Teaching and Research farm of The College of Education, Lanlate to determine the growth characteristics and yield effects of plant spacing and intercropping maize and cowpea. The experimental design used was Randomized Complete Block Design (RCBD) six treatments and five replicates. The treatments were as follows; (1) Cowpea intercropped with maize at $50 \times 50 \mathrm{~cm}$ spacing; (2) Cowpea intercropped with maize at $25 \times 25 \mathrm{~cm}$ spacing; (3) Sole maize at $50 \times 50 \mathrm{~cm}$ spacing; (4) Sole cowpea at $50 \times 50 \mathrm{~cm}$ spacing; (5) Sole maize at $25 \times 25 \mathrm{~cm}$ spacing and (6) Sole cowpea at $25 \times 25 \mathrm{~cm}$ spacing. Each treatment was replicated five times to make thirty (30) experimental plots. The planting of maize (Zea mays) and the cowpea (Vigna unguiculata) was done on 12th June, 2016 with different spacing while the supplying was done a week later. The seeds emerged five days after planting. The plots were kept weed free for the first weeks after planting manually and subsequently done at two week interval. Thinning was done three weeks after planting which was on 27th June, 2016. Thinning was done to reduce the plant to one per stand. The stem height and girth of the cowpea and maize were measured in centimetre $(\mathrm{cm})$ from 2nd week of planting using ruler till the harvesting. At harvesting, number of pods per plant, number of seeds per pod, first day of flowering, weight of the seeds was measured for the cowpea while the number of seeds per cob and the weight of the seed were measured for the maize. The stem height and girth for maize and cowpea were used to evaluate the growth of the crops in each week to harvesting while the number of pods, weight of seeds, flowering period, and weight of cob were used to evaluate the yield of cowpea and maize. Data were analysed by the general linear model statistical procedure with the comparisons of means among treatments with Duncan Multiple Range Test (DMRT). The growth of maize is better when intercropped with cowpea at 50X50 $\mathrm{cm}$ spacing. The growth of maize intercropped with cowpea at $25 \times 25 \mathrm{~cm}$ spacing is better also using the stem height as comparative measure when compared with the sole maize both at $50 \times 50 \mathrm{~cm}$ and $25 \times 25 \mathrm{~cm}$ spacing respectively. It is observed that interplanting of maize and cowpea will really improve the growth and yield of maize and not for the cowpea. A wider spacing for the two crops at $50 \times 50 \mathrm{~cm}$ spacing will also bring a slight increase in the yield of cowpea. It is recommended that to boost the yield maize only and to maximize the available land for planting, planting of maize with cowpea at $50 \times 50 \mathrm{~cm}$ spacing is very important.
\end{abstract}

Keywords: Growth, Intercrop, Maize, Cowpea, Yield, Spacing 


\section{INTRODUCTION}

Intercropping is the process by which two or three different crops are grown on a piece of land in rows next to each other. This method (farming system) helps to increase the profit margin of the farmers in the sense that different crops can be harvested on a piece of land at a particular season (Agbato, 2000; Anil, et al. 2000). The following crops can be intercropped; Cowpea and Maize, Yam and Maize, Tomato and Pepper etc.

Intercropping will suppress the growth of weeds and also helps the farmers to control pest and diseases. The failure of one crop could be compensated by the good growth of the other which output can cover the cost of production. The differences in the depth of rooting, lateral root spread and root densities are some of the factors that affect competition between the component crops in an intercropping system for nutrients (Abdulraheem and Charles, 2013; Carruthers et al 2000). The cereal component, maize in this experiment usually is taller, has a faster growing or move extensive root system particularly a large mass of fine root and is competitive for soil nitrogen closer row spacing increases yield and the smallest row spacing results in the highest yield for maize and cowpea (Abdulraheem, et. al. 2012). Different crops have their own maturity dates and having one crop matures before its companion crop. This reduces the competition between the two crops. Selecting crops or varieties with different maturity date can also assist staged harvesting and separation commodities.

Ezello (1999) reported that intercropping maize is one of the most popular mixed cropping combinations under rain-fed agriculture in the tropics. Cultivation of maize in combination with other crops is therefore a widespread practice in Nigeria, most especially in the South-west. It is not uncommon to see crops like legumes, okra, melon, pepper and cassava being intercropped with maize. In intercropping, sowing crops in the normally recommended uniform row distance would afford little or no opportunity for accommodating a companion crop; hence most African farmers grow around 30,000 maize plants per hectare recommended in a monocrop condition (Alofe et al, 1988).

Maize is essentially an important component of the farming systems and the diet of many people in the tropics and can be processed into different products for various end uses both at the traditional level and industrial scale, though a large production of products utilized in developing countries is obtained via traditional processing while industrial processing meets the bulk of the demand in developed countries (Abdulraheem and Charles, 2013; Ogieva, 1998). The demand for maize is always higher than what is being produced in the country. For instance in the year 2005, over 4.0 million tons of maize was imported from Lebanon, Italy, Belgium and Indian (NBS, 2005) and about 1.772 billion Naira worth of maize was imported in 2006 (NBS, 2006).

Production of average yield of maize is $896-1344 \mathrm{~kg}$ of dry maize/ha in 1979 . This was obtained when maize was planted as sole crop. The yield of late crop was found to be that of the early crop. Yield of cowpea is low when planted ass a sole crop because of serious pest attack, a yield of sole crop $224-672 \mathrm{~kg} /$ ha were obtained while yield of $168-$ $448 \mathrm{~kg} / \mathrm{ha}$ was obtained when the cowpea were intercropped with other crops. Seed yield may be increased to $1680-2240 \mathrm{~kg}$ / ha by the proper timing of insecticides application (Webster and Wilson, 1996).

Intercropping sometimes helps the farmers to improve the fertility of the soil especially cultivation of leguminous crops with pastoral crops e.g. maize intercropped with cowpea. Intercropping also serves as measures for controlling erosion (Webster and Wilson, 1996). 
Maize (Zea mays) is a member of grass family (Gramineae). It is a cereal crop which serves as food for human being and serves as feed for livestock. Maize is an important food crops grown in Nigeria, Ghana and to a lesser extent in Sierra-Leone. It can be grown in an area with a rainfall than $760 \mathrm{~mm}$ in a year. The grain can be prepared in various ways to be eaten by man. It can be boiled or roasted or made into past eaten (Abdulraheem, et. al. 2012).

Cowpea (Vigna unguiculata) is one of the most economical legume crops. Cowpea spacing is $30 \mathrm{~cm} X 30 \mathrm{~cm}$ under sole cropping, this will give 111,111plants/ha, when intercropped with maize, it is sown at a spacing of $60 \mathrm{~cm} \times 30 \mathrm{~cm}$. spacing also depends on varieties approximately $50 \mathrm{~kg}$ of seed per hectare is required.

Maize (Zea mays) and cowpea (Vigna unguiculata) are important components of traditional mixed cropping system in the tropics because of the associated benefits; notable among which are suppression of weeds, maintenance of soil fertility, protection of soil against soil erosion and soil water losses, insurance against crop failure. (Abdulraheem and Charles, 2013)

Intercropping is the growing of two or more crops in proximity to promote interaction between two or more crops to increase the diversity of crops. In intercropping when two crops are grown on a piece of land at the same production season, it will enhance effective utilization of land (Willey and Rerkasen, 1985). Obilana (1998) reported that intercropping is one of the striga control practice in maize production that required minor adjustment in the farming system without any additional inputs.

Intercropping cereals with cowpea in the same row has been reported to give the highest grain yield (Sigh, 1991). Another advantage of intercropping in the same row is reduces striga growth and make weeding easier. Soil fertility is also improved through nutrient recycling in the soil when crops are intercropped (Agbato, 2000). Pest management benefit can also be realized from intercropping due to increases diversity. When two or more crops are grown together, each must have adequate spaces to increase co-operation and minimize competition between them.

Therefore, objectives of the study are to determine the effect of different spacing on the yield of cowpea and maize as a sole crop and when inter-planted; and to determine the effect of interplanting maize and cowpea on their yield.

\section{Materials AND Methods}

The experiment was conducted at the Teaching and Research farm of The College of Education, Lanlate, Oyo State Nigeria during the raining season of year 2016. The experimental design used was Randomized Complete Block Design (RCBD) six treatments and five replicates. The treatments were as follows; (1) Cowpea intercropped with maize at $50 \mathrm{X}$ $50 \mathrm{~cm}$ spacing; (2) Cowpea intercropped with maize at $25 \times 25 \mathrm{~cm}$ spacing; (3) Sole maize at 50 $X 50 \mathrm{~cm}$ spacing; (4) Sole cowpea at $50 \times 50 \mathrm{~cm}$ spacing; (5) Sole maize at $25 \times 25 \mathrm{~cm}$ spacing and (6) Sole cowpea at $25 \times 25 \mathrm{~cm}$ spacing. Each treatment was replicated five times to make thirty (30) experimental plots. Cowpea seeds were procured from the Institutes of Agricultural Research and Training (IAR\&T), Apata, Ibadan while maize seeds were procured from the Nigeria Institutes of Horticulture Research (NIHORT), Idi-ishin, Ibadan.

The planting of maize (Zea mays) and the cowpea (Vigna unguiculata) was done on $12^{\text {th }}$ June, 2016 with different spacing while the supplying was done a week later. The seeds emerged five days after planting. 
The plots were kept weed free for the first weeks after planting manually and subsequently done at two week interval. Thinning was done three weeks after planting which was on $27^{\text {th }}$ June, 2016. Thinning was done to reduce the plant to one per stand.

Karate 2-5EC (Lamdcyhalothrine) was used to spray fourth weeks after planting to combart the leaf hoppers and aphids attacking the cowpea.

At the $2^{\text {nd }}$ weeks after planting, the stem height and girth of the cowpea and maize were measured in $\mathrm{cm}$ using ruler till the harvesting. At harvesting, number of pods per plant, number of seeds per pod, first day of flowering, weight of the seeds were measured for the cowpea while the number of seeds per cob and the weight of the seed were measured for the maize. The stem height and girth for maize and cowpea were used to evaluate the growth of the crops in each weeks to harvesting while the number of pods, weight of seeds, flowering period, and weight of cob were used to evaluate the yield of cowpea and maize.

Data were analysed by the general linear model statistical procedure with the comparisons among treatments with Duncan Multiple Range Test (DMRT).

\section{RESULTS}

Analytical date of surface soil at the site of experiment was shown in table 1. The test soil was sandy-loamy in texture and slightly acidic $(\mathrm{pH}$ 6.0). The Cation Exchange Capacity (CEC) could be rated medium while \% Nitrogen, \% Organic Carbon and available Phosphorus were found to be low in the experimental site according to the fertility classes (FPDD/MANR, 2002).

Table 1: Result of the pre-planting Soil Analysis

\begin{tabular}{|l|l|}
\hline Parameter & Soil Sample \\
\hline $\mathrm{pH}$ & 6.0 \\
\hline Organic Carbon & $1.07 \%$ \\
\hline Organic Matter & $0.62 \%$ \\
\hline Nitrogen $(\mathrm{N})$ & $0.06 \%$ \\
\hline Phosphorus $(\mathrm{P})$ & $0.26 \mathrm{mg} / \mathrm{kg}$ \\
\hline Potassium $(\mathrm{K})$ & $0.23 \mathrm{cmol} / \mathrm{kg}$ \\
\hline Sodium $(\mathrm{Na})$ & $0.39 \mathrm{cmol} / \mathrm{kg}$ \\
\hline Sand & $79 \%$ \\
\hline Silt & $15 \%$ \\
\hline Clay & $6 \%$ \\
\hline
\end{tabular}

Table 2: Effect of intercropping and spacing on the stem height of maize

\begin{tabular}{|l|c|c|c|c|c|c|}
\hline Treatment & \multicolumn{6}{|c|}{ Mean stem height of maize at successive weeks (cm) } \\
\hline & 2 & 3 & 4 & 5 & 6 & 7 \\
\hline Maize 50 X 50cm with Cowpea & $8.74 \mathrm{a}$ & $17.69 \mathrm{a}$ & $27.36 \mathrm{a}$ & $51.07 \mathrm{a}$ & $77.9 \mathrm{a}$ & $142.7 \mathrm{a}$ \\
\hline Maize 25 X 25cm with Cowpea & $13.51 \mathrm{a}$ & $14.86 \mathrm{a}$ & $25.60 \mathrm{a}$ & $36.50 \mathrm{~b}$ & $53.8 \mathrm{~b}$ & $93.10 \mathrm{~b}$ \\
\hline Maize 50 X 50cm & $10.93 \mathrm{a}$ & $14.80 \mathrm{a}$ & $26.82 \mathrm{a}$ & $33.73 \mathrm{~b}$ & $46.94 \mathrm{c}$ & $82.92 \mathrm{c}$ \\
\hline Maize 25 X 25cm & $10.2 \mathrm{a}$ & $13.24 \mathrm{a}$ & $27.27 \mathrm{a}$ & $35.10 \mathrm{~b}$ & $48.39 \mathrm{c}$ & $74.20 \mathrm{~d}$ \\
\hline & $\mathrm{ns}$ & $\mathrm{Ns}$ & $\mathrm{ns}$ & $\mathrm{ns}$ & & \\
\hline
\end{tabular}

Note: Means with same other in the same column are not significantly difference from each other 
Table 3 showed the effect of each treatment on the average stem height of maize plant from the $2^{\text {nd }}$ week till $7^{\text {th }}$ weeks after planting. The stem heights were not significant differences from one another from $2^{\text {nd }}$ week to $4^{\text {th }}$ weeks, also from $3^{\text {rd }}$ week upto $5^{\text {th }}$ weeks. Stem height were not significant differences from one another from $6^{\text {th }}$ weeks to the harvesting time $\left(7^{\text {th }}\right.$ weeks) were the highest stem height in T1 (maize interplanted with cowpea $50 \times 50 \mathrm{~cm}$ spacing, follows by T2 (maize interplanted with cowpea at $25 \times 25 \mathrm{~cm}$ spacing) follow by T3 (Sole maize at $50 X 50 \mathrm{~cm}$ spacing) while the least stem height is T5 (sole maize at $25 \times 25 \mathrm{~cm}$ spacing).

Table 3: Effect of intercropping and spacing on the stem height of cowpea

\begin{tabular}{|l|c|c|c|c|c|c|}
\hline Treatment & \multicolumn{6}{|c|}{ Mean stem height of cowpea at successive weeks (cm) } \\
\hline Cowpea 50 X 50cm with Maize & 2 & 3 & 4 & 5 & 6 & 7 \\
\hline Cowpea 25 X 25cm width Maize & $10.15 \mathrm{a}$ & $13.2 \mathrm{a}$ & $14.85 \mathrm{a}$ & $26.68 \mathrm{c}$ & $32.3 \mathrm{c}$ & $44.5 \mathrm{c}$ \\
\hline Cowpea 50 X 50cm & $12.51 \mathrm{a}$ & $18.07 \mathrm{a}$ & $55.91 \mathrm{~b}$ & $57.26 \mathrm{~b}$ & $60.59 \mathrm{~b}$ \\
\hline Cowpea 25 X 25cm & $8.90 \mathrm{a}$ & $22.53 \mathrm{a}$ & $30.61 \mathrm{a}$ & $71.51 \mathrm{a}$ & $73.47 \mathrm{a}$ & $79.45 \mathrm{a}$ \\
\hline
\end{tabular}

Note: the means with same other in the same column are not significantly difference from each other

The table 3 showed the effect of each treatment on the stem height of Cowpea plant from the $2^{\text {nd }}$ week till $7^{\text {th }}$ weeks after planting. The average stem heights for cowpea shows that all the treatment from $2^{\text {nd }}$ week till harvesting were not significantly difference from one another.

The stem height for the cowpea were not significantly differences from each other from $2^{\text {nd }}$ weeks till $4^{\text {th }}$ weeks. The stem heights for the cowpea were significant difference from one another from $5^{\text {th }}$ weeks till harvesting $\left(7^{\text {th }}\right.$ weeks). The highest stem height for the cowpea was recorded in T4 (sole cowpea at $50 \times 50 \mathrm{~cm}$ ) follow by T2 (cowpea intercropped with maize at $25 \times 25 \mathrm{~cm}$ ) follow by T1 (cowpea intercropped with maize at $50 \times 50 \mathrm{~cm}$ spacing) while the least stem height was recorded in T6 (sole cowpea at $25 \mathrm{X} 25 \mathrm{~cm}$ spacing).

Table 4: Effect of intercropping and spacing on the stem girth of maize

\begin{tabular}{|l|c|c|c|c|c|c|}
\hline Treatment & \multicolumn{6}{|c|}{ Mean stem girth of maize at successive weeks (cm) } \\
\hline & 2 & 3 & 4 & 5 & 6 & 7 \\
\hline Maize 50 X 50cm with Cowpea & $3.30 \mathrm{a}$ & $4.27 \mathrm{a}$ & $4.58 \mathrm{a}$ & $5.56 \mathrm{a}$ & $6.33 \mathrm{a}$ & $7.68 \mathrm{a}$ \\
\hline Maize 25 X 25cm with Cowpea & $3.02 \mathrm{a}$ & $3.64 \mathrm{a}$ & $4.71 \mathrm{a}$ & $5.83 \mathrm{a}$ & $5.81 \mathrm{a}$ & $6.85 \mathrm{a}$ \\
\hline Maize 50 X 50cm & $3.08 \mathrm{a}$ & $3.86 \mathrm{a}$ & $5.16 \mathrm{a}$ & $6.40 \mathrm{a}$ & $6.61 \mathrm{a}$ & $7.04 \mathrm{a}$ \\
\hline Maize 25 X 25cm & $3.01 \mathrm{a}$ & $3.63 \mathrm{a}$ & $4.4 \mathrm{a}$ & $5.18 \mathrm{a}$ & $5.63 \mathrm{a}$ & $6.18 \mathrm{a}$ \\
\hline
\end{tabular}

Note: the means with same other in the same column are not significantly difference from each other

The table above showed the effect of each treatment on the average stem girth of maize plant from the $2^{\text {nd }}$ week till $7^{\text {th }}$ weeks after planting. The stem girths for all the treatments were not significant different from each other for the maize plant from the $2^{\text {nd }}$ week till harvesting $\left(7^{\text {th }}\right.$ weeks).

The maximum stem girth of maize was recorded in T1 (maize intercropped with cowpea at $50 \times 50 \mathrm{~cm}$ spacing) follow by $\mathrm{T} 3$ (sole maize at $50 \times 50 \mathrm{~cm}$ spacing) then $\mathrm{T} 2$ (maize intercropped with cowpea at $25 \times 25 \mathrm{~cm}$ ) while the least stem girth for maize were recorded at $\mathrm{T} 5$ (sole maize at $25 \times 25 \mathrm{~cm}$ spacing). 
Table 5: Effect of intercropping and spacing on the stem girth of cowpea

\begin{tabular}{|l|c|c|c|c|c|c|}
\hline Treatment & \multicolumn{6}{|c|}{ Mean stem girth of cowpea at successive weeks $(\mathrm{cm})$} \\
\hline & 2 & 3 & 4 & 5 & 6 & 7 \\
\hline Cowpea 50 X 50cm with Maize & $1.56 \mathrm{a}$ & $2.14 \mathrm{a}$ & $2.33 \mathrm{a}$ & $3.59 \mathrm{a}$ & $4.27 \mathrm{a}$ & $4.62 \mathrm{a}$ \\
\hline Cowpea $25 \times 25 \mathrm{~cm}$ with Maize & $1.34 \mathrm{a}$ & $1.70 \mathrm{a}$ & $2.63 \mathrm{a}$ & $2.82 \mathrm{a}$ & $3.38 \mathrm{a}$ & $3.88 \mathrm{a}$ \\
\hline Cowpea $50 \times 50 \mathrm{~cm}$ & $1.43 \mathrm{a}$ & $1.75 \mathrm{a}$ & $2.36 \mathrm{a}$ & $2.80 \mathrm{a}$ & $3.21 \mathrm{a}$ & $3.73 \mathrm{a}$ \\
\hline Cowpea $25 \times 25 \mathrm{~cm}$ & $1.56 \mathrm{a}$ & $2.03 \mathrm{a}$ & $2.45 \mathrm{a}$ & $3.04 \mathrm{a}$ & $3.39 \mathrm{a}$ & $4.06 \mathrm{a}$ \\
\hline
\end{tabular}

Note: the means with same other in the same column are not significantly difference from each other

The table above showed the effect of each treatment on the stem height of Cowpea plant from the $2^{\text {nd }}$ week till $7^{\text {th }}$ weeks after planting. The stem girth for all the treatments were not significant different from each other from $2^{\text {nd }}$ weeks till harvesting ( $7^{\text {th }}$ weeks). The maximum stem girth of cowpea was recorded in T1 (cowpea intercropped with maize at $50 \times 50 \mathrm{~cm}$ spacing) followed by T6 (sole cowpea at $25 \mathrm{X} 25 \mathrm{~cm}$ spacing) then $\mathrm{T} 2$ (cowpea intercropped with maize at $25 \times 25 \mathrm{~cm}$ spacing) while the least stem girth were recorded in $\mathrm{T} 4$ (sole cowpea at $50 \times 50 \mathrm{~cm}$ spacing).

Table 6: Effect of intercropping maize with cowpea at different spacing on the yield of maize

\begin{tabular}{|l|c|c|c|}
\hline Treatment & No of seed/plant & Weight of 100 seeds (g) & Biomass (g) \\
\hline Maize 50 X 50cm with Cowpea & $196.3^{\mathrm{a}}$ & $100^{\mathrm{a}}$ & $700^{\mathrm{a}}$ \\
\hline Maize $25 \times 25 \mathrm{~cm}$ with Cowpea & $163.6^{\mathrm{b}}$ & $100^{\mathrm{a}}$ & $620^{\mathrm{b}}$ \\
\hline Maize 50 X50cm & $27.66^{\mathrm{c}}$ & $100^{\mathrm{a}}$ & $540^{\mathrm{c}}$ \\
\hline Maize $25 \times 25 \mathrm{~cm}$ & $25.81^{\mathrm{c}}$ & $100^{\mathrm{a}}$ & $440^{\mathrm{d}}$ \\
\hline
\end{tabular}

Note: the means with same other in the same column are not significantly difference from each other

The table 6 showed the yield using the following parameters, number of seeds/plant, weight seeds and biomass were recorded by maize after harvesting. The table shows that the highest number of seeds/plant was recorded in T1 (maize intercropped with cowpea at 50X50 cm spacing) follow by T2 (maize intercropped with cowpea at $25 \times 25 \mathrm{~cm}$ spacing), then T3 (sole maize at $50 X 50 \mathrm{~cm}$ spacing) while the least number of seed/plant was recorded in T5 (sole maize at 25X25cm spacing). Table 6 also recorded the weight of 100 seeds for all the treatments which was found to be $100 \mathrm{~g}$ for all treatments. The biomass of the maize in $\mathrm{g}$ for all the treatments were also presented. The biomass were significantly differences from each other, the highest biomass was recorded in T1 (maize intercropped with cowpea at $50 \times 50 \mathrm{~cm}$ spacing) follow by $\mathrm{T} 2$ (maize intercropped with cowpea at $25 \times 25 \mathrm{~cm}$ spacing) then $\mathrm{T} 3$ (sole maize at $50 \times 50 \mathrm{~cm}$ spacing) with $\mathrm{T} 5$ (sole maize at $25 \times 25 \mathrm{~cm}$ spacing) recording the least biomass.

Table 7: Effect of intercropping maize with cowpea at different spacing on the yield of cowpea

\begin{tabular}{|l|c|c|c|c|}
\hline Treatment & $\begin{array}{c}\text { No of pod } \\
\text { /plant }\end{array}$ & $\begin{array}{c}\text { No of seeds } \\
/ \text { pod }\end{array}$ & $\begin{array}{c}\text { Weight of } \\
100 \text { seed }(\mathrm{g})\end{array}$ & $\begin{array}{c}\text { Biomass } \\
(\mathrm{g})\end{array}$ \\
\hline Cowpea 50 X 50cm with Maize & $5.15 \mathrm{a}$ & $9.46 \mathrm{a}$ & $50 \mathrm{a}$ & $540 \mathrm{a}$ \\
\hline Cowpea $25 \times 25 \mathrm{~cm}$ with Maize & $6.56 \mathrm{a}$ & $10.92 \mathrm{a}$ & $50 \mathrm{a}$ & $600 \mathrm{~b}$ \\
\hline Cowpea 50 X 50cm & $4.25 \mathrm{a}$ & $8.54 \mathrm{a}$ & $50 \mathrm{a}$ & $420 \mathrm{c}$ \\
\hline Cowpea $25 \times 25 \mathrm{~cm}$ & $3.044 \mathrm{a}$ & $7.89 \mathrm{a}$ & $50 \mathrm{a}$ & $330 \mathrm{~d}$ \\
\hline
\end{tabular}

Note: the means with same other in the same column are not significantly difference from each other 
The table 7 showed the number of pods/plant for the cowpea. The result showed that the number of pod/plants for all treatment were not significantly difference from one another. The table also showed that the highest number of pod/plant was recorded in T2 (cowpea intercropped with maize at 25X25cm spacing) followed by T1 (cowpea intercropped with maize at $50 \times 50 \mathrm{~cm}$ spacing) then $\mathrm{T} 4$ (sole cowpea at $50 \times 50 \mathrm{~cm}$ spacing) while the least was recorded in T6 (sole cowpea at 25X25 $\mathrm{cm}$ spacing).

The table also indicate that the number of seeds/pod were not significant difference from one another. The highest number of seeds/pod was recorded in T2 (cowpea intercropped with maize at $25 \times 25 \mathrm{~cm}$ spacing) followed by $\mathrm{T} 1$ (cowpea intercropped with maize at $50 \times 50 \mathrm{~cm}$ spacing) then $\mathrm{T} 4$ (sole cowpea at 50X50 cm spacing) while the least was recorded in T6 (sole cowpea at 25X25cm spacing);

Weights of 100 seeds for the cowpea for all the treatment were also found not to be significantly differences from each other. Table 7 also recorded the weight of 100 seeds for all the treatments which was found to be $50 \mathrm{~g}$ for all the treatment.

The biomasses of the cowpea for all treatments were presented by this table which shows not to be significant difference from each other. The highest biomass was recorded in T2 (cowpea intercropped with maize at $25 \times 25 \mathrm{~cm}$ spacing) followed by $\mathrm{T} 1$ (cowpea intercropped with maize at $50 \times 50 \mathrm{~cm}$ spacing) then $\mathrm{T} 4$ (sole cowpea at $50 \times 50 \mathrm{~cm}$ spacing) while the least was recorded in T6 (sole cowpea at $25 \mathrm{X} 25 \mathrm{~cm}$ spacing).

\section{Discussions}

The experiment was set up to investigate the effects of interplanting of maize and cowpea at different spacing on the growth and yield of each crop. The results showed that the growth of the maize using stem height as a parameter is better when maize is intercropped with cowpea at $50 \times 50 \mathrm{~cm}$ spacing. The growth of maize intercropped with cowpea at $25 \times 25 \mathrm{~cm}$ spacing is better also using the stem height as a comparative measures when compared with the sole maize both at $50 X 50 \mathrm{~cm}$ and $25 X 25 \mathrm{~cm}$ spacing respectively.

Intercropping maize and cowpea has essential increased the effect on the yield of maize. The best yield (using no of seeds/plant, weight of seeds and biomass of maize and cowpea) was recorded in the treatment where the maize and cowpea were intercropped while relatively lower yield was recorded in sole maize both at $50 \times 50 \mathrm{~cm}$ and $25 \times 25 \mathrm{~cm}$ spacing.

The result also showed that intercropping maize and cowpea has a dominant role over the spacing used, this is because even in a treatment where a wider spacing of $50 \times 50 \mathrm{~cm}$ was used for sowing maize, the yield was comparatively low when compared with a treatment with spacing of $25 \times 25 \mathrm{~cm}$ and the maize is intercropped with cowpea. Although, better yield was recorded in treatment where a wider spacing $50 \times 50 \mathrm{~cm}$ was used in sole maize than in sole maize $25 \times 25 \mathrm{~cm}$ spacing, when the spacing is being compared in the sole maize. The result showed that intercropping maize and cowpea did not have any improvement on the growth and yield of the cowpea using there stem height as a comparative measure to determine the growth of cowpea. Instead the spacing affect truly the growth of the cowpea where the highest plant was recorded in treatment whose have sole maize $50 \times 50 \mathrm{~cm}$.

Interplanting maize and cowpea did not significantly difference in the yield of cowpea when the number of pods/plant, weight of 100 seeds and number of seeds/plant were used as a parameter of yield. There was only a significant difference in the biomass of cowpea whose we have maize intercropping with cowpea at $25 \times 25 \mathrm{~cm}$ spacing. 
It is concluded that interplanting of maize and cowpea will really improve the growth and yield of maize and not for the cowpea. A wider spacing for the two crops at $50 \times 50 \mathrm{~cm}$ spacing will also bring a slight increase in the yield of cowpea. It is recommended that to boost the yield maize only and to maximize the available land for planting, planting of maize with cowpea at $50 \times 50 \mathrm{~cm}$ spacing is very important.

\section{REFERENCES}

Abdulraheem, M.I. and Charles, E.F. (2013): Effects of Geometric row Arrangement on Growth and Yield of Cowpea in a Maize- Cowpea Intercrop. Indian Journal of Innovations and Developments, Indian Society for Education and Environment (ISEE), Volume II, Issue 1, PP 816 - 820. An Online Journal. (http://www.iseeadyar.org/ijid/archvies/jan-13/IJID-1-0115Final\%20Proof.pdf)

Abdulraheem, M.I.; Ojeniyi, S.O and Charles, E.F. (2012): Effect of Different Planting Pattern on Total Dry Matter Production and Maize Forage Quality in Maize (Zea Mays) and Cowpea (Vigna Sinensis) Intercropped as Whole-Crop Forage. International Organization of Scientific ResearchJournal of Agriculture and Veterinary science (IOSR-JAVS), Volume 1, Issue 4, pp 42-46

Agbato, S.O. (2000): Principle and practice of Arable crop production,. Odumatt Press, Oyo. Page 1 - 30

Alofe, O., Elemo, K.A., and Ashaye, T.I. (1998): Cultivation of food crop in the tropics production trends. Pp $16-17$

Anil, L, Park, J. and Phipps, R.H. (2000): The Potential of forage-maize intercrops in Ruminant Nutrition. Animal Feed Science and Technology. 85: 157 - 164

Awoyemi, M.B. (1986): Maize Improvement Production and Utilization in Nigeria. Published by the Maize Association of Nigeria. 223 - 232

Carruthers, K.B., Prithiviral, O. Fe, D., Clautler, R.C. Martin and D.L. Smith (2000): Intercropping Corn with Soybean Lupin and Forgaes; Yield Component Responses. European Journal of Agronomy. 12; 163 - 165

Ezello, O.O. (1996): Characteristics effect of intercropping arable crops in the tropics. New York.

National Bureau of Statistics (NBS) (2005): January - December 2005. Published by NBS, Garki Abuja. 41

National Bureau of Statistics (NBS) (2006): January - December 2006. Published by NBS, Garki Abuja. 46

Obilana, A.B. (1998): Striga studies and control in Nigeria. Proceedings of the second International workshop on Striga. International crops research institute for the semi-arid tropics

Ogieva Erebo (1998): Comprehensive Agricultural Science for Senior Secondary Schools and Colleges. pp 159

Sigh (1991): An appraisal of some intercropping methods in terms of grains yield, response to Applied Phosphorus and monetary return from maize and cowpea. East Africa Agricultural and Forestry Journal. 42(1): $66-70$

Webster, R.W. and Wilson, D.S.O. (1996): An experimental design on intercropping of maize with bush bean in tropical Agriculture, volume 8 and 9, No 12

Willey, R.W. and Rerkasen, B.K. (1985): Intercropping: its importance and research needs, competition and yield advantages. Experimental Agriculture 2: 119 - 133. 